\title{
HRVATSKO KNJIŽNIČARSKO DRUŠTVO \\ KAO NAKLADNIK ZBORNIKA RADOVA SA ZNANSTVENIH \\ I STRUČNIH SKUPOVA
}

\author{
CROATIAN LIBRARY ASSOCIATION \\ AS THE PUBLISHER OF SCIENTIFIC AND PROFESSIONAL \\ CONFERENCE PROCEEDINGS
}

\begin{abstract}
Ana Barbarić
Odsjek za informacijske i komunikacijske znanosti

Filozofski fakultet Sveučilišta u Zagrebu

abarbari@ffzg.hr
\end{abstract}

UDK / UDC 655.4:061.3(091)HKD

Pregledni rad / Review

Prihvaćeno / Accepted: 9. 5.2017.

\section{Sažetak}

Statut Hrvatskoga knjižničarskog društva (HKD-a) u članku 7 u kojem su navedeni cilj i djelatnost Društva, između ostalog, kaže da Društvo objavljuje stručne časopise i druge stručne publikacije te organizira stručne skupove. Kako upravo zbornici radova koji se objavljuju kao pisano svjedočanstvo znanstvenih i stručnih skupova u organizaciji ili suorganizaciji Društva predstavljaju poveznicu dviju istaknutih djelatnosti, cilj je rada prikazati i analizirati taj aspekt nakladničke djelatnosti HKD-a. Posebna pažnja posvećena je redovitim skupovima u organizaciji i/ili suorganizaciji HKD-a i pratećim zbornicima. U zaključnom dijelu rada predstavlja se mogući model tog aspekta nakladničke djelatnosti HKD-a u budućnosti koji bi obuhvaćao objavljivanje zbornika radova u elektroničkom obliku, njihovo daljnje uključivanje u relevantne baze podataka te označavanje radova u zbornicima identifikatorom DOI.

Ključne riječi: Hrvatsko knjižničarsko društvo, HKD, nakladništvo, znanstveni i stručni skupovi, zbornici radova

Vjesnik bibliotekara Hrvatske 60, 1(2017), 23-46

ISSN 0507-1925

(C) VBH 2017. 


\section{Summary}

The Statute of the Croatian Library Association (CLA) in Article 7, indicating the scope and activities of the Association, among other things, claims that the Association publishes professional journals and other professional publications, and organizes professional conferences. Thus, the conference proceedings, published as the written testimony of the scientific and professional conferences organized or co-organized by the Association represent a link that connects these two prominent Association's activities. The aim of the paper is to present and analyze this particular aspect of the publishing activities of the CLA. Special attention was given to the regularly held conferences organized and/or co-organized by the CLA and the accompanying proceedings. A possible future model of this aspect of the CLA publishing activities is presented in the final part of the paper. The model would include the publication of proceedings in electronic form, their further inclusion in the relevant databases, and labeling proceedings papers with DOI identifiers.

Keywords: Croatian Library Association, CLA, publishing, scientific and professional conferences, proceedings

\section{Uvod}

Počeci nakladničke djelatnosti Hrvatskoga knjižničarskog društva (HKD-a) sežu u četrdesete godine 20. stoljeća kada je Društvo objavljivalo hrvatsku bibliografiju. Nakon njegova ponovnog osnutka 1950. godine počinje izlaziti znanstveni i stručni časopis Društva Vjesnik bibliotekara Hrvatske (VBH), najdugovječnija i najznačajnija HKD-ova publikacija. ${ }^{1}$ Od šezdesetih godina prošlog stoljeća, preciznije od 1966. ${ }^{2}$, Hrvatsko knjižničarsko društvo počinje objavljivati i omeđene publikacije. Više od pola stoljeća nakladničke djelatnosti Društva po pitanju objavljivanja omeđenih publikacija nudi priliku za cijeli niz preglednih izlaganja i radova. U radu objavljenom 2014. u časopisu Libellarium ${ }^{3}$, nastalom na temelju izlaganja održanog na 39. skupštini Hrvatskoga knjižničarskoga društva ${ }^{4}$, bavili smo se prijevodima

\footnotetext{
1 Nebesny, Tatjana. Bibliografija izdanja Hrvatskoga knjižničarskog društva : 1940. - 2000. // Hrvatsko knjižničarsko društvo : 14. III. 1940. - 14. III. 2000. : spomenica / [uredila Daniela Živković u suradnji s Aleksandrom Horvat i Aleksandrom Malnar]. Zagreb : Hrvatsko knjižničarsko društvo, 2000. Str. 41.

2 Verona, Eva. Abecedni katalog u teoriji i praksi : [tekst predavanja održanih u studenom 1965. na Seminaru za bibliotekare naučnih biblioteka, prerađen i nadopunjen primjerima]. Zagreb : Društvo bibliotekara Hrvatske, 1966.

3 Barbarić, Ana. Prijevodi IFLA-inih dokumenata u izdanju Hrvatskoga knjižničarskog društva : analiza, stanje, perspektiva [citirano: 2016-12-15]. // Libellarium : časopis za istraživanje pisane riječi, knjige i baštinskih ustanova 7, 2(2014), 197-230. Dostupno na http://www.libellarium.org/ index.php/libellarium/article/view/209

${ }_{4}$ Sadržaj rada je izložen na 39. skupštini HKD-a održanoj u Splitu u listopadu 2014., no rad nije objavljen u tzv. skupštinskom broju Vjesnika bibliotekara Hrvatske koji donosi radove s navedene Skupštine, god. 58, br. 1/2(2015). Op. a.
} 
IFLA-inih dokumenta u izdanju HKD-a koji se, u najvećem broju, u obliku standarda, smjernica i srodnih publikacija objavljuju u nakladničkim nizovima Povremena izdanja Hrvatskoga knjižničarskog društva te Elektronička izdanja Hrvatskoga knjižničarskog društva. Tom smo prilikom ukratko prikazali godine pokretanja i naslove nakladničkih nizova HKD-a uključujući i promjene naslove koje su slijedile promjene u nazivu samog Društva (Društvo bibliotekara Hrvatske, Hrvatsko bibliotekarsko društvo i Hrvatsko knjižničarsko društvo). ${ }^{5}$

Statut Hrvatskoga knjižničarskog društva usvojen u rujnu 2015. u članku 7, u kojem su navedeni cilj i djelatnost Društva, između ostalog, kaže da Društvo objavljuje stručne časopise i druge stručne publikacije te organizira stručne skupove. ${ }^{6}$ Kako upravo zbornici radova koji se objavljuju kao pisano svjedočanstvo znanstvenih i stručnih skupova u organizaciji ili suorganizaciji Društva predstavljaju poveznicu dviju istaknutih djelatnosti, cilj je rada prikazati i analizirati taj aspekt nakladničke djelatnosti HKD-a. Gledajući u prošlost Društva, koja se dijelom može iščitati i iz ranijih verzija njegovih statuta u rasponu od 1975. do 2002. ${ }^{7}$, primjećujemo kako upravo te dvije aktivnosti, objavljivanje publikacija i organizacija skupova, u razdoblju duljem od četrdeset godina predstavljaju temeljne stručne djelatnosti HKD-a. To znači da se uvidom i analizom tema koje su se obrađivale u radovima u HKD-ovim zbornicima može pratiti razvoj knjižničarstva, a i šire, informacijskih i komunikacijskih znanosti u Hrvatskoj, jer su spomenuti zbornici, uz VBH, gotovo do današnjih dana predstavljali skoro pa i jedinu mogućnost za objavljivanje radova na hrvatskom jeziku zainteresiranim autorima. Koliko ti radovi predstavljaju vrijedne stručne, ali i znanstvene doprinose, pokazuje analiza Ivane Hebrang Grgić o zastupljenosti izdanja HKD-a što, naravno, uključuje i zbornike, u važećim programima studija iz područja informacijskih i komunikacijskih znanosti knjižničarskog usmjerenja, kao i u popisima literature diplomskih radova navedenih studija te programima za polaganje stručnih ispita i programima za stalno stručno usavršavanje knjižničara. ${ }^{8}$ Možemo pretpostaviti da bi se radovi iz zbornika u izdanju HKD-a još i više koristili, kako u navedenim dokumentima i izvorima tako i općenito, kad bi bili dostupni u elektroničkom obliku. No o tome ćemo nešto više reći u zaključnom dijelu ovog rada.

\footnotetext{
Barbarić, Ana. Nav. dj. Str. 199-200.

6 Hrvatsko knjižničarsko društvo. Statut [citirano: 2016-12-15]. 18. rujna 2015. Dostupno na http://www.hkdrustvo.hr/hr/statut/.

7 Usp. Hrvatsko bibliotekarsko društvo. Statut. // Vjesnik bibliotekara Hrvatske 21, 1/4(1975), 129-139.; Hrvatsko bibliotekarsko društvo. Statut. // Vjesnik bibliotekara Hrvatske 29, 1/4(1986), 183-195.; Hrvatsko bibliotekarsko društvo. Statut. // Vjesnik bibliotekara Hrvatske 35, 3/4(1992), 237-250.; Hrvatsko knjižničarsko društvo. Statut. // Vjesnik bibliotekara Hrvatske 42, 1/4(1999), 149-166.; Hrvatsko knjižničarsko društvo. Statut. // Vjesnik bibliotekara Hrvatske 45, 3/4(2002), $307-321$.

8 Hebrang Grgić, Ivana. Uloga nakladničke djelatnosti Hrvatskoga knjižničarskog društva u obrazovanju knjižničara. // Vjesnik bibliotekara Hrvatske 58, 1/2(2015), 263-276. Dostupno i na http://hrcak.srce.hr/index.php?show=clanak\&id_clanak_jezik=211894 [citirano: 2016-12-15].
} 


\section{Zbornici radova kao dio nakladničkog niza Izdanja Hrvatskoga knjižničarskog društva}

Hrvatsko knjižničarsko društvo, pod tadašnjim nazivom Društvo bibliotekara Hrvatske, još je 1968. usmjerilo svoju nakladničku djelatnost utemeljivši dva temeljna niza Izdanja Društva bibliotekara Hrvatske i Posebna izdanja Društva bibliotekara Hrvatske. ${ }^{9}$ Preteča Statuta Društva, dokument pod nazivom Pravila Hrvatskoga bibliotekarskoga društva iz 1971., izrijekom navodi stvarne naslove spomenutih nizova. ${ }^{10}$ Treći značajni niz Društva, posebice po kriteriju broja objavljenih publikacija u nizu, predstavljaju Povremena izdanja Hrvatskoga knjižničarskog društva pokrenuta 1978. pod tadašnjim naslovom Povremena izdanja Hrvatskoga bibliotekarskog društva. ${ }^{11}$ Na pokretanje nakladničkih nizova Društva, kao i na njihovu koncepciju, svojom uredničkom vizijom utjecao je, u velikoj mjeri, Aleksandar Stipčević koji je obnašao dužnost glavnog urednika svih nizova Društva od spomenute godine njihova pokretanja, 1968., pa sve do 1984. Do kraja 2002. godine nakladničku djelatnost HKD-a obilježila je činjenica da je jedna jedina osoba bila urednikom svih nakladničkih nizova. Još preciznije, zasebni urednici nizova Izdanja Hrvatskoga knjižničarskog društva i Povremena izdanja Hrvatskoga knjižničarskog društva imenovani su u siječnju 2003. ${ }^{12}$ U tablici 1 donosimo pregled glavnih urednika svih nakladničkih nizova do kraja 2002., a od siječnja 2003. niza Izdanja Hrvatskoga knjižničarskog društva u kojem izlaze zbornici radova.

Tablica 1. Glavni urednici svih nakladničkih nizova HKD-a do kraja 2002. i glavni urednici niza Izdanja Hrvatskoga knjižničarskog društva zaključno s 2016.

\begin{tabular}{|c|c|}
\hline $\begin{array}{c}\text { Glavni urednik/ica } \\
\text { svih nizova HKD-a }\end{array}$ & Obuhvaćeno razdoblje \\
\hline Aleksandar Stipčević & $1968 .-1984$. \\
\hline Nada Gomerčić & $1984 .-1989$. \\
\hline Aleksandra Horvat & $1989 .-1992$. \\
\hline Tatjana Nebesny & $1992 .-2002$. \\
\hline
\end{tabular}

\footnotetext{
9 Nebesny, Tatjana. Nav. dj. Str. 42.

10 Hrvatsko bibliotekarsko društvo. Pravila. // Vjesnik bibliotekara Hrvatske 17, 1/2(1971), $146-151$.

11 Barbarić, Ana. Nav. dj. Str. 197, 200.

12 Gjurković Govorčin, Rajka. Izvještaj o radu Uredničkog odbora izdanja Hrvatskoga knjižničarskog društva za niz Izdanja HKD-a : 2002. - 2004. // Vjesnik bibliotekara Hrvatske 47, 3/4(2004), 159-161. Dostupno i na http://www.hkdrustvo.hr/vbh/broj/85 [citirano: 2016-12-15].
} 


\begin{tabular}{|c|c|}
\hline $\begin{array}{c}\text { Glavni urednik/ica Izdanja Hrvatskoga } \\
\text { knjižničarskog društva }\end{array}$ & Obuhvaćeno razdoblje \\
\hline Rajka Gjurković Govorčin & $2003 .-2007$. \\
\hline Ivana Marinković Zenić & $2007 .-2008$. \\
\hline Irena Kranjec & $2008 .-2012$. \\
\hline Vesna Špac & $2012 .-2014$. \\
\hline Tihomir Marojević & $2014 .-2016$. \\
\hline
\end{tabular}

Urednička koncepcija Aleksandra Stipčevića, prvog glavnog urednika svih nakladničkih nizova Društva, djelomično se razlikuje od sadašnjeg stanja po pitanju vrste i sadržaja publikacija koje tvore pojedine nizove. Aleksandar Stipčević upravo je niz Izdanja Društva bibliotekara Hrvatske (današnji niz Izdanja Hrvatskoga knjižničarskog društva) koncipirao kao niz u kojem neće izlaziti samo zbornici radova sa znanstvenih i stručnih skupova u organizaciji ili suorganizaciji Društva, već u kojem će se objavljivati i znanstvene i stručne knjige inozemnih i hrvatskih autora u kojima se, prvenstveno, obrađuje problematika povijesti knjige, knjižnica i pisma. Međutim posljednja takva publikacija objavljena je još 1991. kao knjiga 25 navedenog niza. Riječ je o djelu Davida Diringera Povijest pisma. ${ }^{13}$ Prateći numeraciju u nizu, sve do kraja 2016., kada je objavljen zbornik radova s 15 . okruglog stola o slobodnom pristupu informacijama koji, naravno, pripada nizu Izdanja Hrvatskoga knjižničarskog društva te je označen kao knjiga 64 navedenog niza, zaključujemo kako je urednička koncepcija Aleksandra Stipčevića promijenjena na način da od devedesetih godina prošlog stoljeća u nizu izlaze isključivo zbornici radova. Gledajući i ostale nizove HKD-a, to je još jasnije od razdoblja koje započinje u siječnju 2003., kada niz Izdanja Hrvatskoga knjižničarskog društva dobiva svog zasebnog glavnog urednika koji je zadužen isključivo za objavljivanje zbornika radova. No to ne znači da je urednička vizija prvog glavnog urednika svih nizova Društva Aleksandra Stipčevića napuštena. Najmlađi niz Društva, niz Hrvatsko knjižničarstvo, u kojem je prva publikacija objavljena 2012., upravo po riječima prve glavne urednice Ivane Hebrang Grgić ima za cilj „,redovito objavljivati kvalitetne znanstvene knjige koje obrađuju teme iz svih područja knjižničarstva, a od posebnog su kulturnog i znanstvenog interesa za Hrvatsku. “14 $\mathrm{S}$ druge strane, u nizu Posebna izdanja Hrvatskoga knjižničarskog društva jedno su vrijeme objavljivane knjige poznatih inozemnih stručnjaka iz područja infor-

13 Diringer, David. Povijest pisma. Zagreb : Hrvatsko bibliotekarsko društvo, 1991.

14 Hebrang Grgić, Ivana. Izvješće glavne urednice niza Hrvatsko knjižničarstvo Hrvatskoga knjižničarskog društva. Izvješća o radu uredništava izdanja Hrvatskoga knjižničarskog društva : za mandatno razdoblje 2010.-2012. // Vjesnik bibliotekara Hrvatske 56, 1/2(2013), 349-350. Dostupno i na http://www.hkdrustvo.hr/vbh/broj/109 [citirano: 2017-01-17]. 
macijskih znanosti te knjižničarstva. Međutim zadnja takva publikacija objavljena je još $2006 .{ }^{15}$ Kada govorimo o knjigama inozemnih stručnjaka, ne mislimo na IFLA-ine standarde i smjernice, čiji se prijevodi objavljuju u nizu Povremena izdanja Hrvatskoga knjižničarskog društva te Elektronička izdanja Hrvatskoga knjižničarskog društva, koji se u katalozima i bibliografijama, ovisno o broju ljudi koji su sudjelovali u izradbi, navode kao publikacije individualnog ili višestrukog autorstva gdje se, ovisno o broju autora, s publikacijom može postupati i kao s anonimnom u proširenom, kataložnom smislu. No vratimo se nizu Posebna izdanja Hrvatskoga knjižničarskog društva. Zadnji izvorni naslov u tom nizu, knjiga hrvatske autorice Tinke Katić, objavljen je još $2007 .{ }^{16}$, da bi u 2008. i 2009. još bio objavljen pretisak oba sveska Pravilnika i priručnika za izradbu abecednih kataloga Eve Verona. Možemo zaključiti kako je niz već dulje razdoblje u mirovanju, s tim da bi prema današnjoj uredničkoj koncepciji HKD-ovih nizova znanstvene i stručne knjige hrvatskih autorica spadale u niz Hrvatsko knjižničarstvo.

Ovaj kratki uvid u ostale nizove HKD-a dovodi nas do zanimljive teme kojom smo se bavili i u radu obavljenu 2014. Tada smo analizirajući broj knjiga objavljenih u nizu Povremena izdanja Hrvatskoga knjižničarskog društva zaključili kako generički stvarni naslovi nizova nisu više prikladni za sadašnje vrijeme i suvremene nakladničke okolnosti. Oni su bili razumljivi u vrijeme kada su ti nizovi bili osmišljavani i pokretani jer se nije moglo znati koliko će često primjerice IFLA objavljivati standarde i smjernice te hoće li biti moguće prevesti sve te dokumente na hrvatski jezik i objaviti ih u izdanju HKD-a. Tim je više i IFLA-ina nakladnička djelatnost sedamdesetih i osamdesetih godina prošlog stoljeća bila usmjerena prvenstveno na područje obrade knjižnične građe, da bi se s vremenom proširila i na ostala područja knjižničarstva. No s obzirom na broj objavljenih publikacija do siječnja 2017. - 32 knjige u nizu Povremena izdanja Hrvatskoga knjižničarskog društva, uz još šest elektroničkih knjiga u nizu Elektronička izdanja Hrvatskoga knjižničarskog društva ${ }^{17}$ - možemo samo ponoviti zaključak iz 2014. da bi vidljivosti i prepoznatljivosti niza, s obzirom na relativno visoku učestalost izlaženja, pridonijela promjena skupnog stvarnog naslova u primjerice Hrvatski prijevodi IFLA-inih izdanja. ${ }^{18}$ Slična primjedba može se uputiti većini stvarnih naslova HKD-ovih nizova. Očigledan izuzetak predstavlja najmlađi niz Hrvatsko knjižničarstvo. Posebice nam se čini spornim stvarni naslov niza kojim se bavimo u ovom radu, zbog činjenice da u njemu sada izlaze zbornici radova, dakle stvarni naslov niza Izdanja Hrvatskoga knjižničarskog društva. Riječ je o gene-

15 Gorman, Michael. Postojana knjižnica : tehnologija, tradicija i potraga za ravnotežom. Zagreb : Hrvatsko knjižničarsko društvo, 2006.

16 Katić, Tinka. Stara knjiga : bibliografska organizacija informacija. Zagreb : Hrvatsko knjižničarsko društvo, 2007.

17 Kako su prijevodi IFLA-inih publikacija objavljivani i u drugim nizovima HKD-a, riječ je, u siječnju 2017. o 51 publikaciji. Usp.: Barbarić, Ana. Nav. dj. Str. 198.

18 Isto, str. 202. 
ričkom naslovu najšireg mogućeg opsega jer zapravo sve publikacije koje HKD objavljuje spadaju pod njegova izdanja. U HKD-ovim dokumentima dostupnim na mrežnim stranicama Društva, kao i u tzv. skupštinskim brojevima Vjesnika bibliotekara Hrvatske, učestalo se brka sveukupnost izdanja HKD-a i spomenuti niz jer je razlika samo u velikom početnom slovu stvarnog naslova niza - Izdanja Hrvatskoga knjižničarskog društva i izdanja Hrvatskoga knjižničarskog društva. Bilježenje u navodnicima, odnosno u kurzivu, stvarnog naslova niza također je vrlo neujednačeno u dokumentima i mrežnim izvorima i pitanje je je li dovoljno razlikovno. Određenoj zbrci pridonosi i korištenje uvriježenog naslova Društvena izdanja kojim se podrazumijevaju sve omeđene publikacije u svim nizovima HKD-a, što možemo zaključiti na temelju tekuće bibliografije koja je dostupna na mrežnim stranicama Društva. ${ }^{19}$ Međutim izraz Društvena izdanja ponekad se koristi i za sva izdanja HKD-a, što uključuje i serijske publikacije, mrežne stranice HKD-a, a možda i stranice Društva na društvenim mrežama. Dakle ponovno možemo zaključiti da generički naslovi nizova nisu prikladni za današnje vrijeme, kada je vidljivost i prepoznatljivost važna, jer ništa ne govore ni o sadržaju ni o vrsti publikacija u tim nizovima, što zasigurno ne pridonosi prodaji samih publikacija. Kako je jasno da se u nizu Izdanja Hrvatskoga knjižničarskog društva nakon 1991. objavljuju isključivo zbornici radova, čini nam se da bi promjena stvarnog naslova niza u Zbornici radova Hrvatskoga knjižničarskog društva bila razumno rješenje.

U nastavku ovog odjeljka nešto ćemo reći o ukupnom broju zbornika radova kojima je nakladnik ili jedan od nakladnika Hrvatsko knjižničarsko društvo (pritom, naravno, uzimamo u obzir i ranije verzije službenog naziva Društva). Većina zbornika radova u izdanju HKD-a objavljena je u nizu Izdanja Hrvatskoga knjižničarskog društva (uključujući i ranije verzije stvarnog naslova niza koje su se mijenjale s promjenom naziva Društva). Ipak neki zbornici radova, kao što će pokazati i naša analiza, ne pripadaju nijednom HKD-ovu nizu. Kao polazište za našu analizu poslužila je već spomenuta tekuća bibliografija koja je pod naslovom Društvena izdanja dostupna na mrežnim stranicama HKD-a. ${ }^{20}$ Bibliografija je analizirana u veljači 2017. Iz analize su izostavljene publikacije s radnim materijalima sa skupština Društva. Naime publikacije s radnim materijalima sa skupština Društva od 2000. donose isključivo program skupštine, autore, naslove i sažetke izlaganja te, eventualno, još neke kraće dokumente koji su delegatima skupštine ponuđeni na usvajanje, dok se cjeloviti radovi izloženi na skupštini objavljuju u tzv. skupštinskim brojevima Vjesnika bibliotekara Hrvatske. Pregledom dostupnih publikacija s radnim materijalima sa skupština ustanovili smo da navedenom odgovaraju radni materijali s 32. skupštine Hrvatskoga knjižničarskog društva „Nova pomagala

19 Društvena izdanja [citirano: 2017-01-17]. // Hrvatsko knjižničarsko društvo. Dostupno na http://www.hkdrustvo.hr/hr/izdanja/kategorija/drustvena/.

20 Isto. 
za novo tisućljeće“" održane u Lovranu u rujnu 2000. (spomenuta publikacija ima 68 stranica) te radni materijali sa svih kasnijih redovnih skupština. Za razliku od toga, radni materijali s 31. skupštine HKD-a „Korisnici u 21. stoljeću - izazov za knjižničarsku struku“ održane u rujnu 1998. u Zadru imaju 153 stranice i sadrže sažetke, proširene sažetke i cjelovite radove. Isti način pripreme radnih materijala karakterističan je i za skupštine prije 1998. Zbog svega navedenog smatramo da bi se u nekom budućem radu trebalo pozabaviti zasebnom analizom radnih materijala sa skupština HKD-a, što bi uključivalo i tzv. skupštinske brojeve Vjesnika bibliotekara Hrvatske.

Opisanom metodologijom, a na temelju analize dostupne bibliografije, utvrdili smo u veljači 2017. brojku od 46 zbornika radova kojima je nakladnik ili jedan od nakladnika Hrvatsko knjižničarsko društvo. Tom brojkom obuhvaćeni su i zbornici radova s redovitih skupova u organizaciji ili suorganizaciji HKD-a koji su tijekom godina promijenili svoj karakter, odnosno od omeđenih su postali serijske publikacije, o čemu će kasnije biti više riječi. Utvrđena brojka od 46 zbornika radova predstavlja $31 \%$ od ukupnog broja od 148 HKD-ovih publikacija navedenih u bibliografiji Društvena izdanja u veljači 2017. ${ }^{21}$ Možemo zaključiti da skoro trećinu izdanja u spomenutoj bibliografiji predstavljaju zbornici radova. Od 46 prepoznatih zbornika radova, samo 10 publikacija (22\%) donosi radove sa skupova koji ne spadaju u skupove koje redovito organizira ili suorganizira HKD. Upravo će tim publikacijama biti posvećen sljedeći odjeljak rada.

\section{Zbornici radova sa skupova koji ne spadaju u redovito organizira- ne skupove HKD-a}

Kao što samo ranije istaknuli, svega 10 zbornika radova od ukupno 46 objavljenih donosi radove sa skupova koji ne spadaju u skupove koje HKD redovito organizira ili suorganizira svake godine ili svake druge godine. Usto, treba reći da postoje i skupovi koje Društvo redovito organizira ili suorganizira, a da ih uopće ne prati objavljivanje zbornika radova. Vrlo je teško općenito utvrditi što sve doprinosi da se prije ili poslije održanog skupa objavi prateći zbornik radova, no vjerojatno na to najviše utječe namjera i ustrajnost članova programskog odbora samog skupa, iz čijih se redova obično i imenuje glavni urednik zbornika. Sljedeća su stvar svakako financijske mogućnosti. U članku 12. Pravilnika o nakladničkoj djelatnosti Hrvatskoga knjižničarskog društva ${ }^{22}$, donesenog u svibnju 2013., stoji da je organizator skupa iz sredstava skupa dužan osigurati najmanje $50 \%$ sredstava za objavljivanje zbornika radova. Prema istom Pravilniku financijsko poslo-

21 Isto.

${ }^{22}$ Hrvatsko knjižničarsko društvo. Pravilnik o nakladničkoj djelatnosti Hrvatskoga knjižničarskog društva [citirano: 2017-02-20]. 2013. Dostupno na http://www.hkdrustvo.hr/hr/dokumenti/ kategorija/pravilnici/. 
vanje vezano uz nakladničku djelatnost u nadležnosti je Glavnog odbora HKD-a (članak 2.), dok je zadaća glavnog urednika (u slučaju zbornika radova niza Izdanja Hrvatskoga knjižničarskog društva) da prijavljuje izdanja iz svog djelokruga na natječaje Ministarstva kulture Republike Hrvatske, Ministarstva znanosti, obrazovanja i sporta Republike Hrvatske ${ }^{23}$, Grada Zagreba, županija, gradova, općina Republike Hrvatske te na natječaje tvrtki (članak 8.). Čanak 8. navodi kako je glavni urednik (u slučaju zbornika radova riječ je o glavnom uredniku niza) taj koji uređuje nakladnički plan iz svog djelokruga te ga šalje na potvrđivanje prvo Stručnom odboru HKD-a, a potom i Glavnom odboru HKD-a. Dakle možemo zaključiti kako je suradnja između programskog odbora skupa i potencijalnog glavnog urednika zbornika radova s glavnim urednikom niza Izdanja Hrvatskoga knjižničarskog društva neophodna za uspjeh koji predstavlja objavljivanje zbornika radova. Naravno, u nakladničkoj povijesti HKD-a postojali su i zbornici radova objavljeni izvan niza Izdanja Hrvatskoga knjižničarskog društva, odnosno izvan bilo kojeg niza, no to je nešto što je bilo karakterističnije za neka ranija razdoblja nakladničkog djelovanja Društva. Izuzetak u tom smislu predstavljaju zbornici seminara Arhivi, knjižnice, muzeji: mogućnosti suradnje u okruženju globalne informacijske infrastrukture koji su pretvorbom iz omeđene u serijsku publikaciju te izmjenjivanjem nakladnika prestali biti dijelom niza Izdanja Hrvatskoga knjižničarskog društva. No zbornicima radova s tog seminara pozabavit ćemo se u zasebnom odjeljku. Slijedi prikaz zbornika radova sa skupova koji ne spadaju u redovito organizirane skupove HKD-a.

Tablica 2. Zbornici radova sa skupova koji ne spadaju u redovito organizirane skupove HKD-a

\begin{tabular}{|l|l|l|l|l|l|}
\hline \multicolumn{1}{|c|}{ Naziv skupa } & $\begin{array}{c}\text { Naslov } \\
\text { zbornika }\end{array}$ & $\begin{array}{c}\text { Glavni } \\
\text { urednik } \\
\text { zbornika }\end{array}$ & $\begin{array}{c}\text { Godina } \\
\text { izdavanja }\end{array}$ & \multicolumn{1}{|c|}{ Niz } & Identifikator \\
\hline $\begin{array}{l}\text { Savjetovanje o } \\
\text { uvođenju Međuna- } \\
\text { rodnog standardnog } \\
\text { bibliografskog } \\
\text { opisa za omeđene } \\
\text { publikacije u biblio- } \\
\text { tečne kataloge }\end{array}$ & $\begin{array}{l}\text { naslov zbor- } \\
\text { nika jednak } \\
\text { je nazivu } \\
\text { skupa }\end{array}$ & $\begin{array}{l}\text { Branka Her- } \\
\text { gešić, Eva } \\
\text { Verona }\end{array}$ & 1975. & $\begin{array}{l}\text { Izdanja } \\
\text { HBD-a } \\
\text { knj. 11 }\end{array}$ & $\begin{array}{l}\text { nema identifi- } \\
\text { katora }\end{array}$ \\
\hline $\begin{array}{l}\text { 2. jugoslavensko } \\
\text { savjetovanje o pri- } \\
\text { mjeni kompjutora u } \\
\text { bibliotekama }\end{array}$ & $\begin{array}{l}\text { naslov zbor- } \\
\text { nika jednak } \\
\text { je nazivu } \\
\text { skupa }\end{array}$ & nije naveden & 1977. & $\begin{array}{l}\text { Izdanja } \\
\text { HBD-a ; } \\
\text { knj. 15 }\end{array}$ & $\begin{array}{l}\text { nema identifi- } \\
\text { katora }\end{array}$ \\
\hline
\end{tabular}

${ }^{23}$ U Pravilniku donesenom 2013. naveden je tadašnji naziv Ministarstva znanosti i obrazovanja. Op.a. 


\begin{tabular}{|c|c|c|c|c|c|}
\hline Naziv skupa & $\begin{array}{l}\text { Naslov } \\
\text { zbornika }\end{array}$ & $\begin{array}{c}\text { Glavni } \\
\text { urednik } \\
\text { zbornika }\end{array}$ & $\begin{array}{c}\text { Godina } \\
\text { izdavanja }\end{array}$ & $\mathrm{Niz}$ & Identifikator \\
\hline $\begin{array}{l}\text { Savjetovanje o } \\
\text { uvođenju Međuna- } \\
\text { rodnog standardnog } \\
\text { bibliografskog } \\
\text { opisa za omeđene } \\
\text { publikacije u biblio- } \\
\text { tečne kataloge }\end{array}$ & $\begin{array}{l}\text { Opisni } \\
\text { elementi } \\
\text { omeđenih } \\
\text { publikacija }\end{array}$ & Eva Verona & 1981. & $\begin{array}{l}\text { Izdanja } \\
\text { HBD-a } \\
\text { knj. } 19\end{array}$ & $\begin{array}{l}\text { nema identifi- } \\
\text { katora }\end{array}$ \\
\hline $\begin{array}{l}\text { 2. interkatedarski } \\
\text { skup nastavnika } \\
\text { bibliotekarstva }\end{array}$ & $\begin{array}{l}\text { Obrazovanje } \\
\text { bibliotekara } \\
\text { na dodi- } \\
\text { plomskoj } \\
\text { razini }\end{array}$ & $\begin{array}{l}\text { Tatjana } \\
\text { Aparac-Ga- } \\
\text { zivoda }\end{array}$ & 1986. & $\begin{array}{l}\text { izvan } \\
\text { nizova } \\
\text { (objav- } \\
\text { ljeno u } \\
\text { sunaklad- } \\
\text { ništvu) }\end{array}$ & $\begin{array}{l}\text { nema identifi- } \\
\text { katora (strojo- } \\
\text { pis autogr.) }\end{array}$ \\
\hline $\begin{array}{l}\text { Znanstveni skup } \\
\text { normizacija osob- } \\
\text { nih imena u knjiž- } \\
\text { ničarstvu i leksi- } \\
\text { kografiji }\end{array}$ & $\begin{array}{l}\text { naslov zbor- } \\
\text { nika jednak } \\
\text { je nazivu } \\
\text { skupa }\end{array}$ & $\begin{array}{l}\text { Dorica Bla- } \\
\text { žević }\end{array}$ & 1996. & $\begin{array}{l}\text { izvan } \\
\text { nizova }\end{array}$ & $\begin{array}{l}\text { ISBN 953- } \\
6001-04-7\end{array}$ \\
\hline $\begin{array}{l}\text { Međunarodno sa- } \\
\text { vjetovanje Narodne } \\
\text { knjižnice - izazov } \\
\text { promjena }\end{array}$ & $\begin{array}{l}\text { Zbornik } \\
\text { radova }\end{array}$ & $\begin{array}{l}\text { Marija Še- } \\
\text { gota-Novak, } \\
\text { Vesna Tur- } \\
\text { čin }\end{array}$ & 1997. & $\begin{array}{l}\text { izvan } \\
\text { nizova } \\
\text { (objav- } \\
\text { ljeno u } \\
\text { sunaklad- } \\
\text { ništvu) }\end{array}$ & $\begin{array}{l}\text { ISBN 953- } \\
97267-0-0\end{array}$ \\
\hline $\begin{array}{l}\text { Stručni skup Pred- } \\
\text { metna obrada - is- } \\
\text { hodišta i smjernice }\end{array}$ & $\begin{array}{l}\text { Zbornik } \\
\text { radova }\end{array}$ & $\begin{array}{l}\text { Jadranka } \\
\text { Lasić-Lazić, } \\
\text { Jelica Le- } \\
\text { ščić, Jasna } \\
\text { Petric }\end{array}$ & 1998. & $\begin{array}{l}\text { Izdanja } \\
\text { HKD-a } \\
\text { knj. } 27\end{array}$ & $\begin{array}{l}\text { ISBN 953- } \\
6001-06-3\end{array}$ \\
\hline $\begin{array}{l}\text { Međunarodni skup } \\
\text { u čast } 100 \text {. godiš- } \\
\text { njice rođenja Eve } \\
\text { Verona }\end{array}$ & $\begin{array}{l}\text { Zbornik } \\
\text { radova }\end{array}$ & $\begin{array}{l}\text { Mirna Wi- } \\
\text { ller, Ana } \\
\text { Barbarić }\end{array}$ & 2007. & $\begin{array}{l}\text { Izdanja } \\
\text { HKD-a; } \\
\text { knj. } 39\end{array}$ & $\begin{array}{l}\text { ISBN 978- } \\
953-6001-39-2\end{array}$ \\
\hline $\begin{array}{l}\text { Stručni skup Iz } \\
\text { povijesti naših } \\
\text { knjižnica }\end{array}$ & $\begin{array}{l}\text { Zbornika } \\
\text { radova }\end{array}$ & $\begin{array}{l}\text { Zorka Renić, } \\
\text { Ilija Pejić }\end{array}$ & 2009. & $\begin{array}{l}\text { izvan } \\
\text { nizova } \\
\text { (objav- } \\
\text { ljeno u } \\
\text { sunaklad- } \\
\text { ništvu) }\end{array}$ & $\begin{array}{l}\text { ISBN 978- } \\
953-6001-58-3\end{array}$ \\
\hline $\begin{array}{l}\text { 10. okrugli stol o } \\
\text { pokretnim knjižni- } \\
\text { cama }\end{array}$ & $\begin{array}{l}\text { Pokretne } \\
\text { knjižnice u } \\
\text { Hrvatskoj }\end{array}$ & $\begin{array}{l}\text { Ljiljana } \\
\text { Vugrinec, } \\
\text { Ljiljana } \\
\text { Crnjar, Frida } \\
\text { Bišćan }\end{array}$ & 2012. & $\begin{array}{l}\text { Izdanja } \\
\text { HKD-a; } \\
\text { knj. } 56\end{array}$ & $\begin{array}{l}\text { ISBN 978- } \\
953-6001-82-8\end{array}$ \\
\hline
\end{tabular}


Analizom podataka iznesenih u tablici 2 uočavamo brojne zanimljivosti. Možemo primijetiti kako je prvi zbornik radova vezan uz područje obrade knjižnične građe, odnosno, još preciznije, uz područje bibliografske organizacije. Ta činjenica sukladna je rezultatima analize objavljene $u$ radu iz 2014. ${ }^{24}$, kada je utvrđeno da je HKD-ovu nakladničku aktivnost u sedamdesetim i osamdesetim godina prošlog stoljeća obilježilo prevođenje IFLA-inih standarda iz područja bibliografske organizacije (pogotovo gledajući s aspekta broja objavljenih publikacija). Jednako je tako zanimljivo da su prva tri zbornika radova objavljena u odgovarajućem nizu, nizu pod tadašnjim naslovom Izdanja Hrvatskoga bibliotekarskog društva. S druge strane, tri od ukupno deset zbornika radova koji ne proizlaze iz skupova koje redovito organizira ili suorganizira HKD, a ne pripadaju nizu Izdanja Hrvatskoga knjižničarskog društva, odnose se na publikacije objavljene u sunakladništvu. Možemo pretpostaviti da je ta činjenica pridonijela neuvrštavanju u odgovarajući niz HKD-a. Jednako je zanimljivo, što se da iščitati iz ISBN-ova spomenutih triju zbornika, da samo jedan od njih ne nosi nakladničku oznaku HKD-a (6001), već nakladničku oznaku sunakladnika, odnosno Gradske knjižnice (tada biblioteke) Rijeka.

Iz prikazanog možemo ustvrditi kako bez obzira na bogatu nakladničku tradiciju HKD-a nije nimalo jednostavno objaviti zbornik radova sa znanstvenog i/ili stručnog skupa koji ne spada u redoviti program HKD-a jer takvi zbornici radova više predstavljaju izuzetak nego pravilo. Već je rečeno da je prema Pravilniku o nakladničkoj djelatnosti $H K D$ - $a$ organizator skupa dužan osigurati najmanje 50\% sredstava za objavljivanje zbornika radova. Zasigurno je lakše prikupiti sredstva, a možda i akumulirati njihov određen dio, kada se skup redovito održava svake godine ili svake druge godine. To nas dovodi do zaključka da se između brojnih skupova u organizaciji ili suorganizaciji $\mathrm{HKD}-\mathrm{a}^{25}$, bez obzira održavaju li se redovito ili su se održali samo jednom, na neki način i na temelju financijskih mogućnosti odlučuje ili čak bira hoće li se objaviti prateći zbornik. Vjerojatno bi bilo bolje kad bi na to izravno i isključivo utjecala kvaliteta programa, aktualnost i svježina teme te mogućnost izlagača da napišu kvalitetan rad.

24 Usp.: Barbarić, Ana. Nav. dj. Str. 197-230.

25 Riječ je primjerice o skupovima Okrugli stol za knjižnične usluge za osobe s posebnim potrebama (u rujnu 2016. održan je 13. put), Okrugli stol za školske knjižnice (u listopadu 2016. održan je 7. put), zatim stručnim skupovima koje u proljeće svake godine organizira HKD, Komisija za knjižnične usluge za djecu i mladež te KGZ, Knjižnica Medveščak pod različitim temama vezanim uz knjižnične usluge za djecu i mladež, potom o okruglim stolovima o zavičajnim fondovima i zbirkama (primjerice 2. okrugli stol Zavičajni fondovi i zbirke u knjižnicama panonskog prostora: u digitalnom okruženju, održan u travnju 2016. u Osijeku), Okrugli stol Strategija razvoja središnjih knjižnica nacionalnih manjina unutar mreže narodnih knjižnica prema prihvaćenom modelu, održan u prosincu 2015. u Zagrebu, Okrugli stol Vrednovanje, upravljanje i zagovaranje ishoda u knjižnicama - mogućnosti uspostave ravnoteže poslovnih i tradicionalnih knjižničarskih vrijednosti, održan u svibnju 2015. u Zagrebu, Stručni skup Dječji odjel - partner obitelji i predškolskoj ustanovi, održan u studenom 2014. u Vinkovcima, Okrugli stol o javnom zagovaranju, održan u svinju 2014. u Splitu itd. Pobrojani su skupovi iz 2014., 2015. i 2016. kojima je HKD bio organizator i suorganizator, a koji nisu popraćeni zbornikom radova uz posebno naznačivanje skupova koji se redovito održavaju. 


\section{Zbornici radova seminara Arhivi, knjižnice, muzeji: mogućnosti suradnje u okruženju globalne informacijske infrastrukture}

Seminari Arhivi, knjižnice, muzeji: mogućnosti suradnje u okruženju globalne informacijske infrastrukture najdugovječniji su redovito održavan znanstveni i stručni skup kojem je Hrvatsko knjižničarsko društvo jedan od suorganizatora. 1. seminar održan je u Rovinju od 19. do 21. studenoga 1997., a 20. u Poreču od 23. do 26. studenoga $2016 .{ }^{26}$ Želimo istaknuti kako ovaj odlomak zasigurno ne predstavlja cjelovitu analizu održanih seminara te pratećih objavljenih zbornika, što je zasigurno tema koja zavređuje zaseban rad, već se želimo osvrnuti na publikacije seminara AKM u izdanju Hrvatskoga knjižničarskog društva u kontekstu problematike nakladničke djelatnosti HKD-a u odnosu na zbornike radova sa znanstvenih i stručnih skupova. Jednako kao što je seminar AKM svojim konceptom iskoračio iz područja knjižničarske struke u područje suradnje svih triju informacijskih i baštinskih struka, arhivističke, knjižničarske i muzejske, što i odgovara suvremenim trendovima u razvoju informacijskih i komunikacijskih znanosti, gdje su stoga i oštre granice među disciplinama i područjima sve manje potrebne i poželjne, tako su i zbornici radova sa seminara AKM u nakladničkoj praksi HKD-a pokrenuli neke nove trendove. Riječ je, dakako, o prerastanju publikacije iz omeđene u serijsku publikaciju, odnosno godišnjak. Uvidom u online katalog Nacionalne i sveučilišne knjižnice u Zagrebu kao hrvatskog bibliografskog središta, preciznije u zapis 000877750 , dobivamo potvrdu da je publikacija pod ključnim naslovom Seminar Arhivi, knjižnice, muzeji serijska publikacija, odnosno godišnjak, koji je do sveska 16, čije je obuhvaćeno kronološko razdoblje 2012. godina, bio omeđena publikacija, odnosno knjiga, te je na taj način i bio obrađivan. Gledajući navedenih 16 svezaka iz razdoblja kada su publikacije seminara Arhivi, knjižnice, muzeji bili knjige, primjećujemo kako je upravo Hrvatsko knjižničarsko društvo bilo nakladnik većine tih zbornika radova. Izuzetak predstavlja publikacija objavljena 2000. u izdanju Hrvatskog muzejskog društva, koja donosi radove s 2. i 3. seminara Arhivi, knjižnice, muzeji: mogućnosti suradnje u okruženju globalne informacijske infrastrukture, održanih 1998., odnosno 1999. Ta je publikacija objavljena u nizu Izdanja Vijesti muzealaca i konzervatora. Zbornik s prvog seminara te zbornike od 4. pa sve do 16. seminara objavljivalo je Hrvatsko knjižničarsko društvo u nizu Izdanja Hrvatskoga knjižničarskog društva. Iako se to možda čini suvišnim isticati, sve su te publikacije, kao i publikacija u izdanju Hrvatskoga muzejskog društva, kao knjige označene identifikatorom ISBN. Taj vrijedni nakladnički poduhvat u svojim je počecima i bio zamišljen tako da se tri temeljna organizatora, tri stručna društva - Hrvatsko arhivističko društvo, Hrvatsko knjižničarsko društvo te Hrvatsko muzejsko društvo - izmjenjuju kao nakladnici publikacije koja se objavljuje jednom godišnje. No HKD je slijedom organizacijskih okolnosti pod

26 Arhivi, knjižnice, muzeji [citirano: 2017-02-20]. Dostupno na http://akm.hkdrustvo.hr/. 
kojima podrazumijevamo i financijske mogućnosti u razdoblju od skoro petnaest godina preuzeo zadaću jedinog nakladnika (uz opisani izuzetak). Promjenom navedenih okolnosti unutar HKD-a, objavljivanje publikacije seminara AKM vraća se prvobitno zamišljenom konceptu, odnosno izmjenjivanju triju stručnih društava kao nakladnika iz godine u godinu. Indikativno je da se ta promjena odigrala istovremeno s promjenom vrste publikacije iz omeđene u serijsku. No prije nego što još nešto kažemo o tome, želimo nešto reći i o promjenama u uredničkoj opremi zbornika radova za vrijeme dok su izlazili kao knjige, koje su, po našem mišljenju, zacrtale put prema promjeni vrste publikacije. Podaci koji će biti izneseni uočeni su pregledavanjem samih publikacija. Zbornik radova s 12. seminara Arhivi, knjižnice, muzeji: mogućnosti suradnje u okruženju globalne informacijske infrastrukture, objavljen 2009., posljednji je zbornik u kojem radovi nisu kategorizirani. U tom smislu on ima sve značajke knjige, ne računajući već spomenuti ISBN, jer su imena triju recenzenata navedena na poleđini naslovnog lista. Znanstvene knjige (monografije) koje se recenziraju kao cjelina u pravilu na sebi nose imena recenzenta te se njihovi dijelovi, koje bi možda bilo ispravnije zvati poglavljima u knjizi nego radovima, ne kategoriziraju. Zbornik s 13. seminara AKM objavljen 2010. možemo označiti kao prijelaznu publikaciju sa zadržavanjem „starih“ i uvođenjem „novih“ značajki. Radovi su kategorizirani te je uz kategoriju rada navedena i oznaka UDK te datum primitka rada, a navedeni podaci predstavljeni su na hrvatskom i engleskom jeziku. Međutim imena recenzenata, kojih je sad znatno više, točnije dvanaest, navedena su na poleđini naslovnog lista. Na sljedećem zborniku s 14. seminara AKM, objavljenu 2012., po prvi se put ne navode imena recenzenata, čime je sačuvana anonimnost recenzije, što je zacijelo značajka znanstvenih i stručnih časopisa te godišnjaka koji su serijske publikacije. Sa stajališta znanstvene komunikacije, takva oprema publikacije predstavlja iskorak te objavljene radove čini prepoznatljivima u smislu zadovoljavanja uvjeta kod klasifikacije radova pri napredovanju u znanstvena zvanja u području društvenih znanosti u koje spadaju informacijske i komunikacijske znanosti. Međutim u tom su smislu potrebni i daljnji iskoraci. Svakako je dobar smjer pretvorba omeđene publikacije u serijsku sa stajališta mogućeg uključivanja u relevantne baze podataka. Međutim i same bibliografske karakteristike publikacije sa seminara AKM opravdavaju takav postupak. Seminar se održava redovito svake godine te se redovito svake godine objavljuje publikacija s prethodnog seminara. Zbog takve redovite učestalosti izlaženja publikaciju je moguće nazvati te kategorizirati kao godišnjak, a godišnjaci su prema svim izdanjima ISBD(S)-a, zatim ISBD(CR)-u te, konačno, objedinjenom ISBD-u, serijske publikacije. ${ }^{27}$ Želimo još istaknuti kako su zbornici radova sa seminara AKM, dok su objavljivani kao knjige, pretežno u

27 U ovom radu i dalje koristimo izraz publikacija, tako da govorimo o serijskim publikacijama, a ne o serijskim jedinicama građe kako propisuje objedinjeni ISBD u kojem je izraz ,publikacija“ napušten. Op. a. Usp. Barbarić, Ana. Predgovor prevoditeljice. ISBD : međunarodni standardni bibliografski opis / preporučila Skupina za pregled ISBD-a ; odobrio Stalni odbor IFLA-ine Sek- 
izdanju HKD-a, u pravilu bili kvalitetno urednički opremljeni. Ti zbornici sadržavaju uredničke predgovore na hrvatskom jeziku i engleskom jeziku, kao i opsežno predmetno kazalo. Osim samih cjelovitih radova sa sažecima i ključnim riječima i na hrvatskom i na engleskom jeziku navedenih prije teksta rada, zbornici donose i sadržajem značajne materijale poput prikaza (uglavnom pojedinih projekata, normi za identifikaciju te obradu građe i slično), zatim prikaze posterskih izlaganja, prikaze održanih radionica te programe seminara, kao i neke druge dodatke poput popisa kratica s objašnjenjima.

Od godišta 17 Arhivi, knjižnice muzeji: mogućnosti suradnje u okruženju globalne informacijske infrastrukture serijska su publikacija s identifikatorom ISSN 1849-4080. Od godišta 17 gubi se podnaslov „zbornik radova“ 28 i sama riječ „,seminar" nije više sadržana u glavnom stvarnom naslovu publikacije, dok se na stranici nasuprot glavnoj naslovnoj stranici navodi puni naziv seminara s kojeg se donose radovi, uključujući redni broj, mjesto i vrijeme održavanja. Od godišta 17 na glavnoj naslovnoj stranici navedena je i tema broja, koja je ujedno i tema seminara, a koja se ranije, dok je publikacija bila omeđena, mogla naći u uredničkom predgovoru. Svako godište uređuju gošće urednice čija su imena navedena na glavnoj naslovnoj stranici, dok je na poleđini glavnog naslovnog lista navedeno uredništvo, odnosno, bolje rečeno, urednički odbor koji čine predstavnici organizatora i suorganizatora, kao i istaknuti inozemni stručnjaci. Ono što nije toliko uobičajeno za serijske publikacije jest učestala promjena glavnog i odgovornog urednika (barem na dosadašnjim godištima koja su objavljena kao serijska publikacija). Godišta 17 i 18 imaju istu glavnu i odgovornu urednicu, dok godište 19 već ima novu. Moguće je da to proizlazi iz izmjene triju nakladnika iz godine u godinu te će biti zanimljivo u budućnosti pratiti hoće li se ta odgovornost ustaliti ili ne. Što se tiče opreme članaka uz ranije navedene kategorije, javlja se i datum primitka, odnosno prihvaćanja rada. Ti su podaci, zajedno s oznakom UDK i kategorijom rada, navedeni i na hrvatskom i na engleskom jeziku na godištima 17 i 19, dok su na godištu 18 oznaka UDK, vrsta rada te datumi primitka i prihvaćanja navedeni samo na hrvatskom jeziku. Stvarni naslovi radova u sva su tri dosad objavljena godišta serijske publikacije AKM i na hrvatskom i na engleskom jeziku, a tekstu radova prethode sažeci na oba jezika s pripadajućim ključnim riječima. Afilijacija autora na godištu 17, koje je prva publikacija seminara AKM objavljena kao serijska, i na hrvatskom je i na engleskom jeziku, kao što je bila i na zbornicima radova od 13. seminara AKM objavljenog 2010. pa do posljednjeg,

cije za katalogizaciju ; [s engleskog prevela i predgovor napisala Ana Barbarić]. Objedinjeno izd. Zagreb : Hrvatsko knjižničarsko društvo, 2014. Str. XI-XIV.

${ }_{28}$ U već spomenutom zapisu u online katalogu Nacionalne i sveučilišne knjižnice u Zagrebu za serijsku publikaciju pod ključnim naslovom Seminar Arhivi, knjižnice, muzeji (ID zapisa 000877750), pregledanom 7. svibnja 2017., među napomenama bilo je zabilježeno da se „Od 19(2016) gubi se drugi podnasl.“ Pregledom samih publikacija utvrđeno je da je ta napomena pogrešna, jer se drugi podnaslov „zbornik radova“ gubi od 17(2014). Op. a. 
16., koji je izašao kao knjiga u izdanju HKD-a, dok je na godištima 18 i 19 samo na hrvatskom jeziku. Jednako tako, urednički predgovor, za razliku od ranijeg razdoblja, sada je samo na hrvatskom jeziku. Predmetno kazalo i programi seminara i dalje su prisutni u publikaciji. Naravno, riječ je o obilježjima koja se mogu mijenjati tijekom izlaženja serijske publikacije.

Ono što svakako predstavlja iskorak u odnosu na vrijeme kada je zbornik radova sa seminara AKM izlazio kao knjiga u izdanju HKD-a jest njegova dostupnost na mreži. Doduše, u ožujku 2017. na mreži je bilo dostupno godište 17 iz 2014. u izdanju Hrvatskog muzejskog društva te godište 18 iz 2015. u izdanju Hrvatskog arhivističkog društva, dok godište 19 objavljeno 2016. u izdanju Hrvatskoga knjižničarskog društva nije bilo dostupno. ${ }^{29}$ Značajke mrežnog izdanja s više su aspekata zbunjujuće, pa možemo pretpostaviti da je riječ o nekakvom privremenom rješenju sa stajališta olakšavanja dostupnosti i poboljšavanja vidljivosti publikacije. Dakle iako je riječ o istom sadržaju kao i u tiskanoj publikaciji, stvarni naslov mrežnog izdanja bitno je različit i glasi AKM časopis. S druge strane, mrežno izdanje trebalo bi imati različit ISSN od tiskanog, dok ovo ima jednak. Vjerojatno zbog toga mrežno izdanje nije prepoznato u Katalogu NSK, odnosno za njega nije izrađen zapis. Iz same mrežne adrese možemo iščitati da je online publikacija na domeni SRCA iako nije uključena u Hrčak: portal znanstvenih časopisa Republike Hrvatske. No možemo pretpostaviti da će se to promijeniti u budućnosti, pod uvjetom da putem Hrčka budu dostupni i zbornici radova. To nas dovodi do zbunjujuće situacije koju bi u budućnosti svakako trebalo razriješiti suradnjom triju nakladnika: online izdanje nazvano je časopisom, za razliku od tiskanog izdanja. Svakako bi trebalo ujednačiti te stvarne naslove: Arhivi, knjižnice, muzeji: mogućnosti suradnje u okruženju globalne informacijske infrastrukture (tiskano izdanje) i AKM časopis (online izdanje) te zatražiti novi identifikator za mrežnu publikaciju. Naravno, to podrazumijeva i smjer razvoja publikacije, hoće li ona ostati zbornik radova (bez obzira na izostavljanje tog podnaslova) jer za sada publikacija prati isključivo seminar AKM ili će zbilja prerasti u časopis, što bi značilo objavljivanje barem još jednog sveščića u godištu koji ne bi donosio izlaganja sa seminara AKM. Takvo što povezano je i s uključivanjem publikacija u odgovarajuće baze podataka.

I za kraj ovog osvrta, vratimo se Hrvatskom knjižničarskom društvu kao nakladniku. Zanimljivo je da je zapis za godište 19 serijske publikacije seminara AKM uvršten u bibliografiju Društvena izdanja na mrežnim stranicama HKD-a u koju se inače ne uvrštavaju serijske publikacije u izdanju HKD-a poput Vjesnika bibliotekara Hrvatske i HKD Novosti, i to s korporativnom odrednicom, kao da je riječ o omeđenoj publikaciji. ${ }^{30}$ Izgleda da prijelaz publikacije iz omeđene u serijsku na mnogo razina izaziva nedoumice i zbrku, no s druge strane nudi i pregršt mogućnosti za bibliografsku analizu koje nismo sve ni iscrpili u ovom prikazu.

29 AKM časopis [citirano: 2017-0302]. Dostupno na http://hrcak.srce.hr/ojs/index.php/akm/index.

30 Društvena izdanja. Nav. dj. 


\section{Zbornici radova okruglih stolova o slobodnom pristupu informa- cijama}

Okrugli stolovi o slobodnom pristupu informacijama redovito se održavaju od 2001. Prvi održani okrugli stol sadržavao je u nazivu i temu, tako da mu je naziv glasio Okrugli stol Slobodan pristup informacijama u službi kulturnog razvitka. Održan je, kao i kasniji okrugli stolovi, u povodu Međunarodnog dana ljudskih prava 10. prosinca $2001 .{ }^{31}$ Nakon toga naziv priredbe ustalio se u obliku „okrugli stol o slobodnom pristupu informacijama“" uz navođenje teme svakog okruglog stola u prednjem naslovu zbornika radova te na poleđini glavnog naslovnog lista. Uključujući prosinac 2016., održano je ukupno šesnaest okruglih stolova koje prate objavljeni zbornici u izdanju HKD-a, s tim da neke publikacije donose radove s dva okrugla stola. Važno je istaknuti da sve publikacije nose podnaslov „zbornik radova“" te da su sve objavljene u nizu Izdanja Hrvatskoga knjižničarskog društva. $\mathrm{Na}$ ovom ćemo mjestu istaknuti da spomenuti niz ima identifikator ISSN 1846554 koji se na publikacijama niza bilježi od 2006. Kao što smo ranije istaknuli vezano uz publikacije seminara Arhivi, knjižnice, muzeji: mogućnosti suradnje u okruženju globalne informacijske infrastrukture, ovaj odjeljak ne predstavlja cjelovit prikaz zbornika radova s okruglih stolova o slobodnom pristupu informacijama, već je rasprava usmjerena na značajke spomenutih publikacija kao dijela analiziranog nakladničkog niza. Usto, moramo istaknuti da je nakon deset održanih okruglih stolova objavljen rad u kojem se detaljno prikazuju i analiziraju tim razdobljem obuhvaćeni programi okruglih stolova te zbornici radova. ${ }^{32}$ Organizatori okruglih stolova o slobodnom pristupu informacijama su Komisija za slobodan pristup informacijama Hrvatskoga knjižničarskog društva te Katedra za bibliotekarstvo Odsjeka za informacijske i komunikacijske znanosti Filozofskog fakulteta u Zagrebu. Nakladnik svih publikacija je, kao što smo već istaknuli, Hrvatsko knjižničarsko društvo. Još preciznije, do sad je održano šesnaest okruglih stolova, a objavljeno je dvanaest publikacija. U jednoj publikaciji zajednički su objavljeni radovi s 2. i 3 . okruglog stola, kao i radovi s 4 . i 5 okruglog stola, zatim radovi s 7. i 8 okruglog stola te radovi s 13. i 14. okruglog stola. Upravo je posljednjom navedenom publikacijom unesena značajna novost u nakladničku praksu HKD-a po pitanju objavljivanja zbornika radova. Spomenuti zbornik radova objavljen 2014. donosi radove s 13. okruglog stola održanog 2013. te radove s 14. okruglog stola održanog 2014. Važno je istaknuti da je publikacija objavljena neposredno prije održavanja 14. okruglog stola u prosincu 2014., što znači da se

\footnotetext{
31 Ovisno o tome je li 10. prosinca, Međunarodni dan ljudskih prava, u pojedinim godinama bio u subotu ili nedjelju, neki su okrugli stolovi bili održani u dane blizu tog datuma. Op. $a$.

32 Barbarić, Ana; Ivana Hebrang Grgić; Aleksandra Horvat. Deset godina Okruglog stola o slobodnom pristupu informacijama : analiza zbornika i programa. // 11. okrugli stol o slobodnom pristupu informacijama : zbornik radova / uredile Ana Barbarić i Ivana Hebrang Grgić. Zagreb : Hrvatsko knjižničarsko društvo, 2012. Str. 73-97.
} 
od te godine istovremeno održava okrugli stol te se objavljuje publikacija koja donosi izlaganja u obliku radova i prije nego što su se ona održala (zbornik radova objavljuje se uoči skupa). Riječ je o jedinom zborniku radova u izdanju ili suizdanju HKD-a koji se od 2014. objavljuje neposredno prije skupa. Takva promjena bila je neophodna za još jedan važan iskorak do kojeg je HKD kao nakladnik došao baš tom publikacijom. Naime od 2014. zbornik se referira u bazi Academic Search Premier (EBSCOhost). Ističemo da je riječ o jedinom zborniku radova u izdanju ili suizdanju HKD-a koji se referira u nekoj bazi. Svakako bi taj put trebale slijediti i ostale publikacije sa znanstvenih i/ili stručnih skupova u organizaciji ili suorganizaciji HKD-a.

Pregledavajući zbornike radova s okruglih stolova o slobodnom pristupu informacijama možemo zaključiti da su oni dosljedno urednički oblikovani i opremljeni. Prema bibliografskim značajkama zbornici radova pripadali bi u omeđene publikacije ili knjige, međutim promjenama u navođenju identifikatora i oni od 2012. mijenjaju svoj karakter, čime postaju godišnjaci, odnosno serijske publikacije. Ipak radovi u zbornicima ni prije ni poslije 2012. nisu kategorizirani, a nije navedena ni njihova oznaka UDK. Imena recenzenata, i to samo dvaju, navedena su na poleđini glavnog naslovnog lista. Prije samog rada naveden je naslov na hrvatskom jeziku, kao i sažetak s ključnim riječima na hrvatskom jeziku. Naslov na engleskom jeziku, kao i sažetak s ključnim riječima na istom jeziku, nalazi se na kraju rada, što je bilo prisutno u znanstvenim i stručnim časopisima u nekim prošlim vremenima, dok je danas karakterističnije za znanstvene monografije. Zbornici radova bogato su urednički opremljeni te donose brojene dodatke uz sadržaj koji prate okrugle stolove. Uz urednički predgovor na hrvatskom i engleskom jeziku, zbornici radova donose, također u dvojezičnom obliku, program okruglog stola, životopise predavača te zaključke s prethodnog okruglog stola. Publikacije donose popis sudionika s odgovarajućeg okruglog stola, a ponekad i neke kraće dokumente u dodacima, poput manifesta, deklaracija i slično, dok su oni izlagači koji nisu dostavili izlaganje u obliku cjelovitog rada zastupljeni sažecima na hrvatskom i engleskom jeziku.

No u katalogu Nacionalne i sveučilišne knjižnice u Zagrebu u zapisu 000885156 (ID zapisa) vidimo da je riječ o serijskoj publikaciji koja je do godišta 12 za obuhvaćeno razdoblje 2012., a koje je objavljeno 2013., bila opisivana kao knjiga. Naime od godišta 2013./2014., objavljenog 2014., na publikaciji se javlja novi identifikator ISSN 1849-5109 koji prati ključni naslov Slobodan pristup informacijama. Taj se podatak bilježi na publikaciji ispod skupnog stvarnog naslova Izdanja Hrvatskoga knjižničarskog društva, potom odgovarajuće numeracije u nizu te pripadajućeg ISSN-a niza 1846-5544. Jasno je da je taj „,dodatni“ ISSN zatražen kako bi se zbornik radova mogao početi referirati u bazi Academic Search Premier, što je, kako smo već istaknuli, značajan i potreban korak. Jednako tako, zbornici radova od spomenute godine na sebi više ne 
nose identifikator za omeđene publikacije, odnosno ISBN, što možemo iščitati iz spomenutog zapisa u Katalogu NSK, gdje stoji da su ranija godišta bila obrađena kao knjige. Iz podataka kako su predstavljeni na stranici nasuprot glavne naslovne stranice, primjenom bibliografskih odredbi, možda bi se moglo i zaključiti da je i dalje riječ o omeđenoj publikaciji koja pripada nakladničkom nizu koji ima svoj ISSN, a potom u taj nakladnički niz spada i kolo koje, pak, ima vlastiti ISSN. Upravo je tako objašnjeno u uredničkom predgovoru zbornika radova objavljenog 2014. Urednice Tea Grašić-Kvesić i Ivana Hebrang Grgić pišu: „Od sada će zbornici Okruglog stola o slobodnom pristupu informacijama, osim oznake niza izdanja Hrvatskoga knjižničarskog društva (ISSN 1846-5544), nositi i ISSN oznaku kola Slobodan pristup informacijama (ISSN 1849-5109).“33 Međutim izostanak ISBN-a i uvod u spomenuti zapis NSK govori nam da je i ta publikacija u izdanju HKD-a prerasla iz omeđene u serijsku, odnosno u godišnjak. Ono što je malo zbunjujuće jest da je publikacija u potpunosti jednako urednički opremljena i da je zadržala sve svoje značajke, s izuzetkom navođenja novog ISSN-a i izostavljanja ISBN-a, i u razdoblju kad je bila omeđena i kad je postala serijska, odnosno godišnjak. Kako taj godišnjak, prema zapisu iz Kataloga NSK, upravo ima identifikator ISSN 1849-5109, publikacija je u Katalog NSK uvedena pod ključnim naslovom Slobodan pristup informacijama, koji je identičan glavnom stvarnom naslovu. Čini nam se da je u ovom slučaju želja programskog odbora okruglog stola da se publikacija referira u nekoj od relevantnih baza podataka potaknula ovu promjenu, iako ona nije utjecala na većinu značajki same publikacije, pa čak ni na mišljenje urednica o kakvoj je vrsti publikacije riječ. Iz toga možemo zaključiti da je na tu promjenu prvenstveno utjecalo koordinirano djelovanje Hrvatskog ureda za ISBN i ISSN-ureda Hrvatske, a ne sama volja uredničkog odbora HKD-a, glavnog urednika niza Izdanja Hrvatskoga knjižničarskog društva te urednica samih zbornika, odnosno HKD-a kao nakladnika da se promjeni vrsta publikacije. Nekakvu, iako ne jasnu, potvrdu za to možemo naći u zapisima zbornika s okruglog stola objavljenih od 2014. i uvrštenih u bibliografiju Društvena izdanja na mrežnim stranicama HKD-a pod korporativnim odrednicama kao da je i dalje riječ o knjigama. Kao što smo već ranije istaknuli, spomenuta bibliografija ne donosi zapise za serijske publikacije u izdanju HKD-a poput Vjesnika bibliotekara Hrvatske i HKD Novosti, za razliku od zapisa za zbornike radova koji su prerasli, na ovaj ili onaj način, u serijske publikacije, što nije do kraja ujednačen kriterij. ${ }^{34}$

33 Grašić-Kvesić, Tea; Ivana Hebrang Grgić. Predgovor. // Slobodan pristup informacijama : 13. i 14. okrugli stol : zbornik radova / uredile Tea Grašić-Kvesić i Ivana Hebrang Grgić. Zagreb : Hrvatsko knjižničarsko društvo, 2014. Str. IX.

34 Društvena izdanja. Nav. dj. 


\section{Zbornici radova s dana specijalnih i visokoškolskih knjižnica}

Dani specijalnih i visokoškolskih knjižnica redovito se održavaju od 1999. Skup je spomenute godine pokrenut pod nazivom „dani specijalnoga knjižničarstva Hrvatske“, da bi 2004. promijenio, odnosno proširio naziv, tako da su te godine bili održani 6. dani specijalnih i visokoškolskih knjižnica. Da je riječ o istom skupu, ukazuje neprekinuta numeracija skupa. Dakle „dani“ su prvi put održani 19. i 20. travnja 1999. u Rijeci, a po petnaesti put održat će se od 17. do 20. svibnja 2017. u Lovranu. Do sad je objavljeno jedanaest publikacija, od kojih prva donosi radove i priloge s 1. i 2. danâ specijalnoga knjižničarstva Hrvatske. Očekuje se da će u prvoj polovici 2017. biti objavljen i zbornik radova s 14. danâ specijalnih i visokoškolskih knjižnica, tako da će se broj publikacija popeti na dvanaest. Tijekom prvog desetljeća svog održavanja, od 1999. do 2009., skup se održavao svake godine, što završava s 11 . danima specijalnih i visokoškolskih knjižnica, da bi se potom prešlo na održavanje skupa svake druge godine, što je vjerojatno i primjerenije hrvatskim prilikama, uzimajući pritom u obzir i njihov financijski aspekt. Takva promjena u učestalosti održavanja skupa odrazila se i na broj objavljenih publikacija. Usto, 6. dani specijalnih i visokoškolskih knjižnica koji su se održali 19. i 20. travnja 2004. u Opatiji po temom „Knjižnični sustavi hrvatskih sveučilišta“ nisu popraćeni zbornikom radova. ${ }^{35}$ Prvi objavljeni zbornik radova koji donosi radove i priloge s 1. i 2. danâ specijalnoga knjižničarstva nije dio nijednog nakladničkog niza HKD-a. Visina hrpta te publikacije je $29 \mathrm{~cm}$, tako da publikacija i dimenzijama odudara od ostalih zbornika radova u izdanju Društva. Gledajući sadržaj same publikacije, na što, uostalom, ukazuje i stvarni naslov, uočavamo da zbornik uz cjelovite radove sadrži i priloge koji su priloženi u obliku ppt-prezentacija. Na publikaciji nisu navedeni recenzenti, a radovi nisu kategorizirani. Na jednak način oblikovan je i zbornik radova s 3. danâ specijalnoga knjižničarstva Hrvatske, s tim da je ta publikacija uobičajenih dimenzija, odnosno visina hrpta joj je $24 \mathrm{~cm}$. Organizator „dana“ u tom početnom razdoblju bila je samo Sekcija za specijalne knjižnice Hrvatskoga knjižničarskog društva. Možemo zaključiti da početni objavljeni zbornici radova s navedenog skupa predstavljaju začetak vrijednog nakladničkog napora HKD-a koji traje do današnjih dana te da se kroz urednički koncept i oblikovanje publikacije može, na neki način, pratiti i razvoj struke: prvo je bilo važno objaviti publikaciju, odnosno radove, a kasnije je postalo važno da su publikacije recenzirane, a potom i radovi kategorizirani.

35 6. dani specijalnog knjižničarstva Hrvatske Knjižnični sustavi hrvatskih sveučilišta (Opatija, 19. i 20. travanj 2004.). // HKD Novosti 25 (ožujak 2004), str. 30-31. Dostupno i na http://www. hkdrustvo.hr/hkdnovosti/ [citirano: 2017-03-11]. Najava skupa u tekstu objavljenu u HKD Novostima naslovljena je 6. dani specijalnog knjižničarstva, dok se u samom tekstu spominje novi naziv 6. dani specijalnih i visokoškolskih knjižnica. Iz toga možemo zaključiti da je 2004. bila u tom smislu prijelazna godina. Uz tekst koji predstavlja najavu skupa objavljen je i program skupa. Iz njega možemo vidjeti da su predavači bili rektori i prorektori hrvatskih sveučilišta, prodekani pojedinih fakulteta, ravnatelji sveučilišnih knjižnica, državni tajnik te načelnici u odgovarajućim ministarstvima i slično. Vjerojatno je i takav sastav predavača utjecao na činjenicu da zbornik radova nije objavljen. Op. $a$. 
Kao što smo već istaknuli, „dane“ je u njihovu začetku organizirala samo Sekcija za specijalne knjižnice HKD-a. Od zbornika radova s 4. danâ specijalnog knjižničarstva Hrvatske, održanih 2002., redoviti organizator postaje i Nacionalna i sveučilišna knjižnica u Zagrebu. Od zbornika radova sa 7. danâ specijalnih i visokoškolskih knjižnica, održanih 2005., kao organizator javlja se sekcija u promijenjenom nazivu, što se odrazilo na naziv skupa, dakle od tada je riječ o Sekciji za specijalne i visokoškolske knjižnice HKD-a. Na istom zborniku radova kao organizatori se javljaju i Sveučilišna knjižnica Rijeka te Knjižničarsko društvo Rijeka. Sveučilišna knjižnica Rijeka navedena je i na nekim kasnijim zbornicima kao organizator odgovarajućih „,dana“. Od 4. danâ specijalnoga knjižničarstva Hrvatske, održanih 2002., zbornici radova postaju dio niza Izdanja Hrvatskoga knjižničarskog društva. Dakle od tada zbornici radova ne sadržavaju više radove i priloge, već samo radove. Ističemo da se za „dane“ zbornici radova objavljuju nakon održanog skupa, što znači da je godina izdavanja zbornika kalendarska godina nakon održavanja skupa u vrijeme kad se skup održavao svake godine. Nakon promjene učestalosti održavanja skupa na svake dvije godine, učestalost objavljivanja zbornika radova u odnosu na održani skup postaje promjenjiva te obuhvaća razdoblja od jedne godine, kao i razdoblja od dvije godine. Od zbornika radova s 5. danâ specijalnog knjižničarstva Hrvatske, objavljena 2004. (s tim da je skup održan 2003)., radovi su recenzirani, s tim da su imena, u pravilu, dvaju recenzenta navedena na poleđini glavnog naslovnog lista. Možemo zaključiti da se zbornik radova recenzirao kao cjelina, odnosno kao knjiga, s tim da u tom razdoblju radovi nisu bili kategorizirani. Određene promjene vidimo na novijim zbornicima radova s tog skupa. Tako zbornik radova s 13. danâ specijalnih i visokoškolskih knjižnica, objavljen 2014., na poleđini glavnog naslovnog lista donosi imena čak 21 recenzenta, uz kategorizaciju radova. Je li to početak prelaska te publikacije iz omeđene u serijsku, ostaje da se vidi. Publikacija je zasad nesumnjivo omeđena jer kao identifikator ima ISBN. Međutim očito je da 21 recenzent nije recenzirao publikaciju u cjelini, već samo po jedan ili, možda, više radova, čime se kreće prema konceptu vrednovanja karakterističnijem za serijske publikacije, odnosno znanstvene časopise. Još bismo istaknuli da su od spomenutog zbornika radova s 5. danâ specijalnoga knjižničarstva Hrvatske, objavljena 2004., radovi uz naslov na hrvatskom jeziku opremljeni i naslovom na engleskom jeziku te da radove prate sažeci s ključnim riječima na oba jezika. Od iste publikacije i urednički je uvod ne samo na hrvatskom već i na engleskom jeziku. Afilijacija autora u svim se zbornicima navodi samo na hrvatskom jeziku.

Možemo zaključiti kako bi zbog njegovih nakladničkih, a osobito sadržajnih posebnosti, bilo dobro i zborniku radova s tzv. ,specijalki“ posvetiti poseban rad, odnosno posebno istraživanje. Takvo što nije bio cilj ovog kratkog prikaza, u kojem smo se tek osvrnuli na karakteristike publikacija s ovog skupa u kontekstu nakladničke djelatnosti HKD-a po pitanju objavljivanja zbornika radova. U svjetlu rasprave pretvorbi zbornika radova iz omeđene u serijsku publikaciju, zbornici radova sa „specijalki“ nisu nimalo sporni: oni su nesumnjivo omeđene publika- 
cije, na što nam dokazuje i uvid u Katalog Nacionalne i sveučilišne knjižnice u Zagrebu kao hrvatskoga bibliografskog središta, u kojem su svi zbornici radova sa spomenutog skupa uneseni pod odgovarajućom korporativnom odrednicom te $u$ zapisima obrađeni kao knjige.

\section{Zaključna razmatranja}

Objavljivanje zbornika radova sa znanstvenih i stručnih skupova u organizaciji ili suorganizaciji Hrvatskoga knjižničarskog društva nesumnjivo predstavlja jednu od najvažnijih aktivnosti Društva. Ne želimo podcjenjivati znanstvene i/ ili stručne skupove u organizaciji ili suorganizaciji HKD-a koji nisu popraćeni zbornikom radova, ali bez prateće publikacije izrečeno na skupu s vremenom odlazi u zaborav i ne može se koristiti kao stručna literatura za unapređenje struke, školovanje budućih knjižničara te cjeloživotno učenje postojećih knjižničarskih stručnjaka. Jednako tako, postupci i propisi koji uređuju i znanstveno i stručno napredovanje podrazumijevaju objavljivanje radova, danas svakako i recenziranih i kategoriziranih, a za znanstveno napredovanje i uključenih u relevantne baze podataka. Zbog svega navedenog smatramo da analizirani aspekt nakladničke djelatnosti HKD-a u budućnosti treba ojačati. Iako je knjižničarska struka možda čak i emocionalno vezana uz tiskanu knjigu, čini nam se da bi po pitanju zbornika iskorak u nakladničkoj djelatnosti HKD-a predstavljalo objavljivanje zbornika u elektroničkom obliku na mreži. Naravno, tu se odmah postavlja pitanje mogućnosti otvorenog pristupa koji bi u smislu znanstvene, kao i stručne, komunikacije bio poželjan. Drugo je pitanje je li to financijski moguće, čime se ovaj rad i nije mogao baviti jer bi nam za takav izračun trebali konkretni financijski pokazatelji nakladničkog poslovanja HKD-a. Međutim možda bi se u okviru Društva mogao izraditi model koji bi uključivao i financijski aspekt, a iz kojeg bi bilo vidljivo bi li objavljivanje zbornika isključivo u elektroničkom obliku omogućilo da veći broj skupova u organizaciji ili suorganizaciji HKD-a bude popraćen zbornikom, odnosno jesu li knjižnice kao pretežni kupci publikacija HKD-a spremne plaćati licenciju za pristup e-zbornicima u izdanju HKD-a. Naravno, tu je indikativan primjer publikacije AKM, čiji se nakladnici sada izmjenjuju na način da im je HKD nakladnik svake treće godine, jednako kao i Hrvatsko arhivističko društvo te Hrvatsko muzejsko društvo. Upravo su zadnja dva spomenuta društva, usudili bismo se reći, bez nekog velikog mudrovanja, istovremeno objavila tiskanu publikaciju AKM seminara, kao i njenu mrežnu inačicu u otvorenom pristupu. Kao što smo već istaknuli, taj bi vrijedni nakladnički poduhvat trebalo unaprijediti po pitanju usklađivanja stvarnog naslova tiskanog i mrežnog izdanja te po pitanju traženja zasebnog ISSN-a za mrežno izdanje, no i ovako je riječ o značajnom iskoraku, koji na određeni način i HKD-u ukazuje na poželjan, a očito i moguć, smjer. Možda je u vremenima kada je HKD kao nakladnik objavljivao prosječno četiri do pet 
novih naslova godišnje takvu produkciju bilo nemoguće financirati iz redovitih sredstva dobivenih za poslovanje HKD-a te su bili neophodni i novci zarađeni prodajom publikacija. No posljednjih je godina broj novih naslova sveden na jedan do dva, najviše tri godišnje. Možda bi se u takvim prilikama zbornici i mogli u otvorenom pristupu postaviti na mrežu uz uvjet da organizator skupa u tu svrhu predvidi određena sredstva, a da ostatak sredstava potrebnih za troškove priređivanja publikacije osigura Društvo. Takvo što svakako bi pridonijelo vidljivosti Društva i njegova rada te zacijelo pozitivno utjecalo na čitanje i citiranje radova objavljenim u e-zbornicima. Takav bi model zahtijevao i dodatni iskorak, koji se i očekuje od knjižničarske struke, čije područno-specifične kompetencije obuhvaćaju uporabu različitih identifikatora za različite vrste bibliografskih entiteta. Riječ je o identifikatoru DOI (Digital Object Identifier). Uvidom u Hrčak: portal znanstvenih časopisa Republike Hrvatske možemo primijetiti da je sve više hrvatskih časopisa uključeno u navedeni sustav, pa tako primjerice i časopis Libellarium. Ispravan redoslijed vjerojatno bi bio da se temeljna publikacija HKD-a, znanstveni i stručni časopis Vjesnik bibliotekara Hrvatske, koji je dostupan na mreži u otvorenom pristupu, prvi uvede u navedeni sustav. No i moguće objavljivanje zbornika radova u izdanju HKD-a u elektroničkom obliku otvorilo bi mogućnost da se radovi u tim zbornicima označe navedenim identifikatorom, što bi zacijelo dodatno poboljšalo vidljivost radova hrvatskih autora iz područja knjižničarstva u umreženom svijetu u kojem danas svi živimo i radimo te objavljujemo.

\section{LITERATURA}

AKM časopis [citirano: 2017-0302]. Dostupno na http://hrcak.srce.hr/ojs/index.php/ $\mathrm{akm} / \mathrm{index}$

Arhivi, knjižnice, muzeji [citirano: 2017-02-20]. Dostupno na http://akm.hkdrustvo.hr/

Barbarić, Ana; Ivana Hebrang Grgić; Aleksandra Horvat. Deset godina Okruglog stola o slobodnom pristupu informacijama : analiza zbornika i programa. // 11. okrugli stol o slobodnom pristupu informacijama : zbornik radova / uredile Ana Barbarić i Ivana Hebrang Grgić. Zagreb : Hrvatsko knjižničarsko društvo, 2012. Str. 73-97.

Barbarić, Ana. Predgovor prevoditeljice. ISBD : međunarodni standardni bibliografski opis / preporučila Skupina za pregled ISBD-a ; odobrio Stalni odbor IFLA-ine Sekcije za katalogizaciju; [s engleskog prevela i predgovor napisala Ana Barbarić]. Objedinjeno izd. Zagreb : Hrvatsko knjižničarsko društvo, 2014. Str. XI-XIV.

Barbarić, Ana. Prijevodi IFLA-inih dokumenata u izdanju Hrvatskoga knjižničarskog društva : analiza, stanje, perspektiva [citirano: 2016-12-15]. // Libellarium : časopis 
za istraživanje pisane riječi, knjige i baštinskih ustanova 7, 2(2014), 197-230. Dostupno na http://www.libellarium.org/index.php/libellarium/article/view/209

Diringer, David. Povijest pisma. Zagreb : Hrvatsko bibliotekarsko društvo, 1991.

Društvena izdanja [2017-01-17]. // Hrvatsko knjižničarsko društvo. Dostupno na http:// www.hkdrustvo.hr/hr/izdanja/kategorija/drustvena/

Gjurković Govorčin, Rajka. Izvještaj o radu Uredničkog odbora izdanja Hrvatskoga knjižničarskog društva za niz Izdanja HKD-a : 2002. - 2004. // Vjesnik bibliotekara Hrvatske 47, 3/4(2004), 159-161. Dostupno i na http://www.hkdrustvo.hr/vbh/ broj/85 [citirano: 2016-12-15].

Gorman, Michael. Postojana knjižnica : tehnologija, tradicija i potraga za ravnotežom. Zagreb : Hrvatsko knjižničarsko društvo, 2006.

Grašić-Kvesić, Tea; Ivana Hebrang Grgić. Predgovor. // Slobodan pristup informacijama : 13. i 14. okrugli stol : zbornik radova / uredile Tea Grašić-Kvesić i Ivana Hebrang Grgić. Zagreb : Hrvatsko knjižničarsko društvo, 2014. Str. IX-XII.

Hebrang Grgić, Ivana. Izvješće glavne urednice niza Hrvatsko knjižničarstvo Hrvatskoga knjižničarskog društva. Izvješća o radu uredništava izdanja Hrvatskoga knjižničarskog društva : za mandatno razdoblje 2010.-2012. // Vjesnik bibliotekara Hrvatske 56, 1/2(2013), 349-350. Dostupno i na http://www.hkdrustvo.hr/vbh/broj/109 [citirano: 2017-01-17].

Hebrang Grgić, Ivana. Uloga nakladničke djelatnosti Hrvatskoga knjižničarskog društva u obrazovanju knjižničara. // Vjesnik bibliotekara Hrvatske 58, 1/2(2015), 263-276. Dostupno i na http://hrcak.srce.hr/index.php?show=clanak\&id_clanak_jezik=211894 [citirano: 2016-12-15].

Katić, Tinka. Stara knjiga : bibliografska organizacija informacija. Zagreb : Hrvatsko knjižničarsko društvo, 2007.

Nebesny, Tatjana. Bibliografija izdanja Hrvatskoga knjižničarskog društva : 1940. 2000. // Hrvatsko knjižničarsko društvo : 14. III. 1940. - 14. III. 2000. : spomenica / [uredila Daniela Živković u suradnji s Aleksandrom Horvat i Aleksandrom Malnar]. Zagreb : Hrvatsko knjižničarsko društvo, 2000. Str. 41-55.

Hrvatsko bibliotekarsko društvo. Pravila. // Vjesnik bibliotekara Hrvatske 17, 1/2(1971), 146-151.

Hrvatsko bibliotekarsko društvo. Statut. // Vjesnik bibliotekara Hrvatske 21, 1/4(1975), 129-139.

Hrvatsko bibliotekarsko društvo. Statut. // Vjesnik bibliotekara Hrvatske 29, 1/4(1986), 183-195.

Hrvatsko bibliotekarsko društvo. Statut. // Vjesnik bibliotekara Hrvatske 35, 3/4(1992), 237-250. 
Hrvatsko knjižničarsko društvo. Pravilnik o nakladničkoj djelatnosti Hrvatskoga knjižničarskog društva [citirano: 2017-02-20]. 2013. Dostupno na http://www.hkdrustvo. $\mathrm{hr} / \mathrm{hr} /$ dokumenti/kategorija/pravilnici/

Hrvatsko knjižničarsko društvo. Statut. // Vjesnik bibliotekara Hrvatske 42, 1/4(1999), 149-166.

Hrvatsko knjižničarsko društvo. Statut. // Vjesnik bibliotekara Hrvatske 45, 3/4(2002), 307-321.

Hrvatsko knjižničarsko društvo. Statut [citirano: 2016-12-15]. 18. rujna 2015. Dostupno na http://www.hkdrustvo.hr/hr/statut/

6. [šesti] dani specijalnog knjižničarstva Hrvatske Knjižnični sustavi hrvatskih sveučilišta, (Opatija, 19. i 20. travanj 2004.). // HKD Novosti 25 (ožujak 2004), str. 30-31. Dostupno i na http://www.hkdrustvo.hr/hkdnovosti/ [citirano: 2017-03-11].

Verona, Eva. Abecedni katalog u teoriji i praksi : [tekst predavanja održanih u studenom 1965. na Seminaru za bibliotekare naučnih biblioteka, prerađen i nadopunjen primjerima]. Zagreb : Društvo bibliotekara Hrvatske, 1966. 